\title{
Species diversity and spatial variation in fish assemblage structure of streams in connected tropical catchments in northern Australia with reference to the occurrence of translocated and exotic species
}

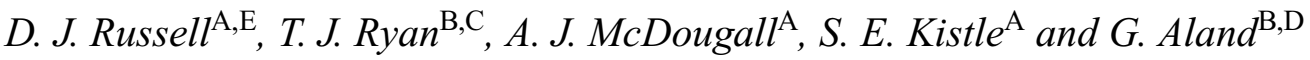 \\ A Northern Fisheries Centre, Queensland Department of Primary Industries, PO Box 5396, Cairns, \\ Qld 4870, Australia. \\ ${ }^{B}$ Queensland Department of Natural Resources and Mines, Freshwater Fisheries and Aquaculture Centre, \\ Walkamin Research Station, Walkamin, Qld 4872, Australia. \\ ${ }^{\text {C}}$ Present address: Arthur Rylah Institute, 123 Brown St., Heidelberg, Vic. 3084, Australia. \\ DPresent address: Queensland Boating and Fisheries Patrol, 6 Herbert St., Bowen, Qld 4805, Australia. \\ ${ }^{\mathrm{E}}$ Corresponding author. Email: john.russell@dpi.qld.gov.au
}

\begin{abstract}
The freshwater piscifauna of the watercourses of the Barron and Mitchell systems, two northern Australian catchments with adjacent headwaters, was surveyed. Fifty-eight species of fish from 26 families, including several marine vagrants, were sampled from the freshwater reaches of the Barron River, compared to 28 species from 15 families from the Mitchell River. Species diversity and richness was higher in the coastal section of the Barron catchment owing to the influence of marine vagrants and species that were estuarine dependent for part of their life cycle. Detrended correspondence analysis of fish abundance data showed that sites in the coastal Barron catchment and the Mitchell catchment were widely separated in ordination space. Historically, barriers to fish movement determined species composition in both catchments, but there have been major changes in species composition as a result of extensive translocations of native fish into the Barron catchment over the last 50 years. Five species of exotic fish, including the cichlids Tilapia mariae and Oreochromis mossambicus, were established in the Barron system and one species in the Mitchell catchment. Cherax quadricarinatus, a crustacean endemic to western drainages, has been translocated into the Barron catchment and has since become widely established. This has implications for the interbasin transfer of irrigation water between the Barron and the Mitchell catchments potentially providing a mechanism for fish, including the exotic species $O$. mossambicus, to spread across northern Australia.
\end{abstract}

\section{Introduction}

The wet tropics of north-eastern Australia are conservatively thought to contain about two thirds of the freshwater fish families occurring in Australia and $~ 80 \%$ of those found in northern Australia (Pusey and Kennard 1996). These authors noted a strong latitudinal gradient in fish assemblage structure of wet-tropics watercourses, with groups of northern streams and southern streams containing the most distinctive faunas. The seven remaining catchments, which included the Barron River, formed a homogenous group with little interbasin separation, probably because they shared analogous hydrologies, water quality and contained a similar array of habitats. It was also noted that discontinuities in stream profile had a strong effect on the presence and abundance of many species, but that some species, notably Mogunda adspersa and Anguilla reinhardtii, had mechanisms that allowed them to move past stream barriers. A study of fish diversity in a north Queensland tropical stream (the Black-Alice River) found that total fish diversity decreased with distance upstream, and this was almost entirely a result of a sequential decrease in species numbers (Beumer 1980). Beumer also noted that lower diversities in the upper reaches are indicative of the instability of the flow regime in that part of the system. Accordingly, Pusey et al. (1995) have suggested that predictable and constant flow regimes may allow for the development of restricted habitat requirements and a greater degree of partitioning of a range of habitat types, thus leading to increased species richness within a river.

Earlier studies of the freshwater fishes of the Barron River catchment (Shipway 1947a, 1947b, 1947c, 1948) have identified 21 species of freshwater fish, of which at least seven were found above the Barron Falls. More recent surveys of smaller tributary streams above the Barron Falls have recorded eight species of freshwater fish including some that may have been translocated (Pusey and Kennard 
1996). These studies identified four species that also occur in westward-flowing rivers of the Gulf of Carpentaria and suggested that their presence in the Barron may be the result of landscape evolution during the early quaternary. Several phylogeographic studies suggest that the current genetic structure of some freshwater fish in streams of north-eastern Queensland is strongly affected by changes in drainage patterns due to geomorphological processes that occurred in the recent past (Hurwood and Hughes 1998, 2001; McGlashan and Hughes 2000, 2001, 2002). In the wet tropics, passive and anthropogenic translocations, linkages of watersheds during flood events and cross-catchment movement of irrigation water are all mechanisms that could potentially contribute to inter-catchment dispersal of fish (Hurwood and Hughes 1998; Russell et al. 2000). Russell et al. (2000) flagged cross-catchment movement of exotic fish from the Barron to the Mitchell catchment as an emerging management issue.

There is evidence that the Australian freshwater fish fauna are under pressure from a range of influences including man-made environmental changes (Lake 1971), translocation of some native fishes (Barlow et al. 1987) and the introduction of exotic species (McKay 1984; Ivantsoff and Aarn 1999). Translocation of native fish species into rivers or the new habitats created by the construction of impoundments (McKay 1989) has been widely practiced in Australia, including in the wet tropics, ostensibly for the purpose of creating recreational fisheries. Much of the translocation activity in the Barron catchment occurred after the completion of Tinaroo Falls Dam in 1958. There have also been unsuccessful attempts to establish the non-native recreational fish species including rainbow (Salmo gairdnerii) and brown (Salmo trutta) trout in streams and impoundments on and adjacent to the Barron River (Grant 1975), with some attempts dating back to early last century.

It has been suggested that, although well adapted to harsh environmental conditions and pronounced seasonal fluctuations, Australian native fish show little evidence of specialisation (McKay 1984). Ironically, this lack of specialisation may increase the vulnerability of native fishes to domination, reduction and perhaps complete eradication by some exotic species. Australian inland waters have been colonised by at least 21 freshwater fish species introduced to the continent (Arthington and Lloyd 1989; McKay 1989). Arthington (1989) argued that, although there was evidence that introduced fishes have not seriously altered aquatic habitats, competition for food, perhaps mediated by interference and aggression, may impact native species. There was also evidence that some introduced species prey directly on the eggs and juvenile native fishes (Ivantsoff and Aarn 1999). Translocated fishes may trigger localised extinctions. At its type locality Barlow et al. (1987) documented a decline in abundance and eventual extinction of the Lake Eacham rainbowfish (Melanotaenia eachamensis), suggesting predation by translocated indigenous species as the cause. Melanotaenia eachamensis has subsequently been identified at other locations in north Queensland (Allen 1989; Pusey et al. 1997) but remains absent from the type locality.

In this study, we document the fish assemblage structure of two interconnected catchments from different river basins in northern Australia, including the occurrence and possible effects of translocated and exotic species.

\section{Material and methods}

\section{Study sites}

In northern Australia, there are two coastal drainage systems: the north-eastern slopes, which includes the Barron River and other wet tropic streams; and the Gulf of Carpentaria, which includes the streams of the Mitchell catchment (Fig. 1). The Barron River is a relatively large $\left(2190 \mathrm{~km}^{2}\right)$ coastal catchment on the Queensland wet-tropical coast draining into the Coral Sea near the city of Cairns $\left(16^{\circ} 56^{\prime} \mathrm{S}\right.$ and $\left.145^{\circ} 47^{\prime} \mathrm{E}\right)$. The Barron River system is arguably the most heavily regulated of all north Queensland streams. The catchment has five impoundments including two major storages: Tinaroo Falls Dam (which impounds Lake Tinaroo) on the upper Barron River; and Copperlode Dam (which impounds Lake Morris) on Freshwater Creek. Lake Tinaroo is the largest impoundment, with a storage capacity of $436.5 \mathrm{GL}$, a surface area of $33.7 \mathrm{~km}^{2}$ and a shoreline length of $209 \mathrm{~km}$. The other major impoundment, Copperlode Dam, is situated on the upper reaches of Freshwater Creek and has a storage capacity of 44.5 GL, a surface area of $3.1 \mathrm{~km}^{2}$ and shoreline length of $\sim 39 \mathrm{~km}$. These impoundments do not have fishways incorporated into their structure. Tinaroo Falls Dam feeds the Mareeba-Dimbulah Irrigation Area (MDIA) through a network of irrigation channels, siphons and balancing storages. Channel infrastructure, including the siphons and regular vertical drops of up to a metre or more, are barriers to upstream fish movement. In some areas, a channel system has been constructed to provide regulated flows of irrigation water in natural watercourses. A feature of the MDIA is that some of the waters are diverted by gravity-fed open channels across the Great Dividing Range into the western flowing Walsh and Mitchell River catchments. As well as irrigation, water from Tinaroo Falls Dam is used for hydroelectric power generation at the Barron Falls, domestic purposes and for livestock. Lake Tinaroo has major recreational uses including boating, fishing and swimming, whereas Lake Morris is used to supply domestic water to the City of Cairns and assists with flood mitigation. The Barron Falls, a $\sim 300 \mathrm{~m}$ high waterfall $\sim 17 \mathrm{~km}$ from the mouth, acts as a barrier to most upstream fish movements. To assist in data analyses, the Barron catchment was divided into five sub-catchments (see Fig. 1). Criteria used to split the sub-catchments were: discontinuities that act as barriers to fish movements (the Barron Falls and Tinaroo Falls Dam); distance from the river mouth; and land use. In the Barron catchment, freshwater sites were defined as being upstream of the limit of tidal influence and included all sites above and below the Barron Falls and on Freshwater Creek (Fig. 1). Coastal sites were all below the Barron Falls and non-coastal sites were above the Falls.

The Mitchell River rises on the Hann Tableland and flows in a generally westerly direction to drain into the Gulf of Carpentaria. The mean annual discharge at Koolatah $\left(15^{\circ} 57^{\prime} \mathrm{S}, 142^{\circ} 23^{\prime} \mathrm{E}\right)$ in the lower catchment was 12.36 million ML and the peak annual discharge was $4336 \mathrm{~m}^{3} \mathrm{~s}^{-1}$ (Queensland Department of Natural Resources and Mines, personal communication). The Mitchell catchment is one of the largest in Australia and, including the Walsh, Palmer and Alice River sub-catchments, has a total area of $\sim 71710 \mathrm{~km}^{2}$. Study sites were located in both the upper Mitchell and Walsh sub-catchments (Fig. 1). 

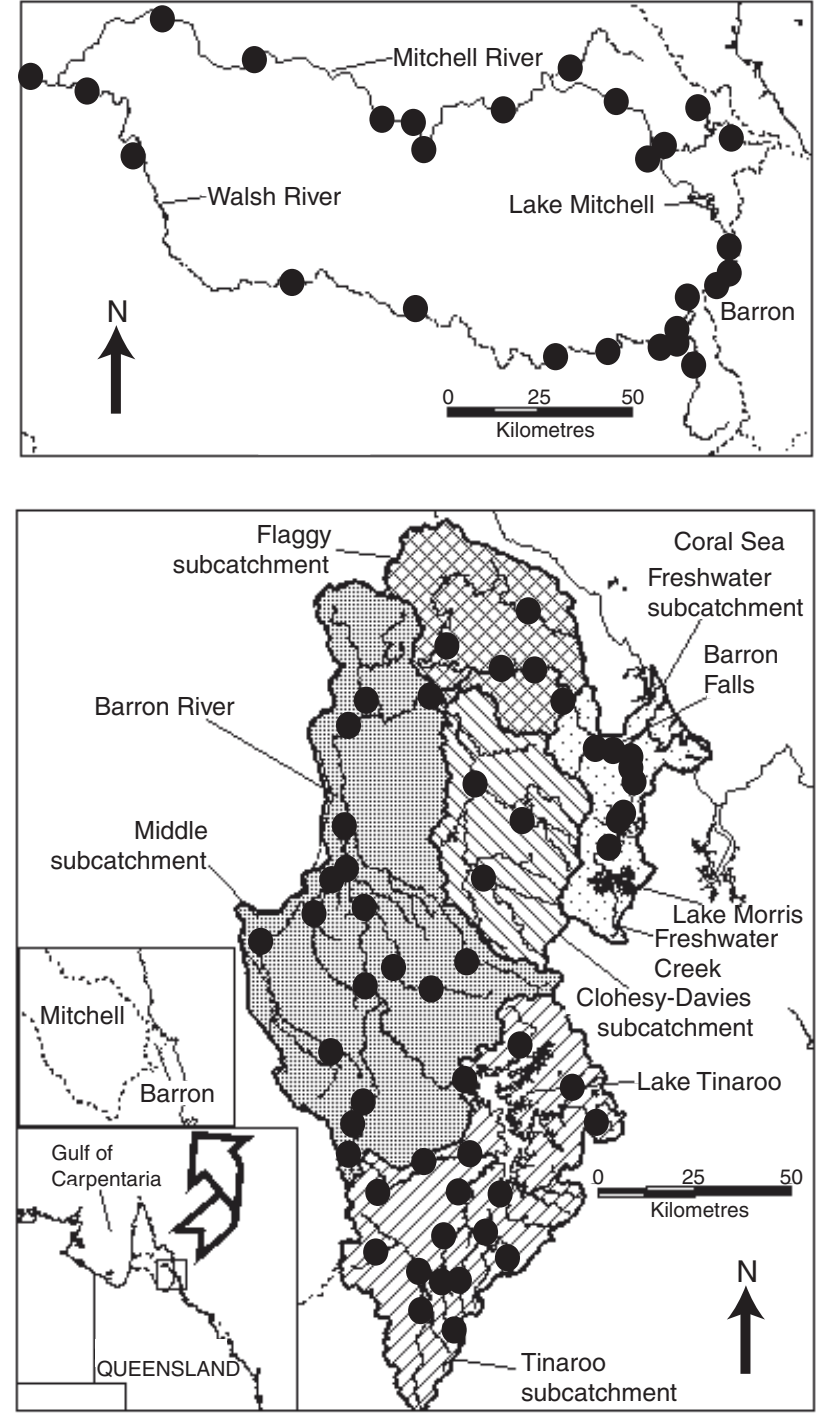

Fig. 1. Fish sampling sites (-) in the upper Mitchell (top) and Barron (below) catchments. Shaded areas show the individual Barron sub-catchments (bottom map) and dotted lines show the catchment boundaries in the top map and in the insets.

The Walsh River, which has a catchment area of $\sim 8988 \mathrm{~km}^{2}$, has four weirs from 70 to $980 \mathrm{ML}$ total storage capacity. The Mitchell River is impounded by Lake Mitchell (129000 ML storage capacity). The Mitchell River Falls $\left(16^{\circ} 23^{\prime} \mathrm{S}, 143^{\circ} 55^{\prime} \mathrm{E}\right)$ are located $\sim 350 \mathrm{~km}$ from the mouth, just upstream of the confluence of the Mitchell and Walsh Rivers.

The climate of north Queensland is characterised by a very high rainfall during the hot summer months (December to February) and a relatively dry, mild winter (June to August).

\section{Sampling}

The freshwater fish at 54 sites on streams in the Barron catchment and 25 sites in the upper Mitchell catchment (Fig. 1) were sampled on four separate occasions (twice per year) between May 1997 and December 1998. Sampling was confined to streams in both catchments, with no sampling undertaken either in the impoundments of the Barron catchment or in Lake Mitchell. A translocated species is defined as an indigenous fish that is not endemic to the catchment, whereas exotic fish are not native to Australia. Several references including Shipway $(1947 a, 1947 b, 1947 c, 1948)$ and Pusey and Kennard (1996), as well as anecdotal evidence on the activities of now defunct stocking groups, have been used to assist to determine if fish species in the two catchments are likely to have been translocated.

Sites on smaller streams of both catchments were electrofished using a Smith-Root Model 12 back pack (Smith-Root, Vancouver, WA, USA), whereas five sites on the lower Barron River (both above and below the Barron Falls) were assessed using a generator powered Smith-Root Model 7.5 GPP electrofisher (Smith-Root) fitted to a $4.3 \mathrm{~m}$ vessel. Electrofishing was conducted along the banks or in areas of likely fish habitat, such as woody debris, rocks and overhanging riparian vegetation. Total electrofishing time was recorded and varied from site to site, but was generally between 30 to 60 min duration, depending on local conditions. At each site, stunned fish were identified and counted. Most fish were released. Specimens that were difficult to identify in situ were retained and later preserved for more detailed examination. All Barron sites were fished twice per year: May-June 1997, August-November 1997, March-June 1998 and September-December 1998. The Mitchell sites were also sampled twice per year: July-September 1997, November-December 1997, April-June 1998 and September-October 1998. Other supplementary fishing techniques including dip-, gill- and seine netting were used periodically to update the catchment fish species inventory. Catch per unit effort (CPUE) for each species at each site was calculated by standardising the catches to number of fish caught per $1000 \mathrm{~s}$ of electrofishing time. For the ordination analyses, CPUE data for both catchments were pooled and then averaged for each site for all sampling occasions.

\section{Data analyses and ordinations}

Detrended correspondence analyses (DCA) were performed to analyse site/abundance data of fish in both catchments using the software CANOCO, which is an extension of the Cornell Ecology program DECORANA (Hill 1979). The data were double square root transformed for analysis. Double square root transformations were used to focus attention on patterns within the whole community, mixing contributions from both common and rare species (Carr 1996). Some species that could not be fully identified because they were juveniles and present in low numbers were excluded from the analyses.

Diversity indices $\left(\mathrm{H}^{\prime}(\mathrm{S})\right)$ were calculated using the ShannonWeiner function and were thematically plotted on maps using MapInfo software (MapInfo Corporation, Troy, NY, USA). The Genstat statistical package (VSN International Ltd, Herts, UK) was used to develop models to relate species diversity and species richness to independent environmental and geographical parameters. A multiple linear regression model was used for the species diversity regressions, but for species richness, a generalised linear model (GLM) with a log link function was chosen. This was because species richness is more likely to follow a Poisson distribution than a normal distribution. In both analyses, best subsets regression and forwards stepwise regression were used for selecting the terms to be included in the model. At each step, correlations between the proposed terms to be added and the terms already in the model were made. If the proposed term was significantly correlated (at the 5\% level) with any of the other terms, it was excluded and next best term was then trialed. Both selection processes arrived at the same model. The independent variables used for each site in the Barron catchment were: distance from the river mouth; height above sea level; distance to Tinaroo Dam; distance up a tributary from the main river channel; stream order; conductivity; suspended solids; total nitrogen; total phosphorus; maximum water depth; and an index of riparian disturbance (Russell et al. 2000). With exception of the last two parameters, these were also used as independent variables for the 
Mitchell River analyses. The water quality values were the average of all measurements taken from the surface waters at the individual sites. At the Barron sites, these measurements were made monthly between November 1997 and May 1998 and at the Mitchell sites, they were made at the same time that the fish were sampled (twice per year).

\section{Results}

Over the period May 1997 to December 1998, 53336 fish were collected from 54 sites in the freshwater parts of the Barron River. In the upper Mitchell catchment from July 1997 to October 1998, 17453 fish were sampled from 25 freshwater sites. Fifty-eight species of fish from 26 families, including several marine vagrants were identified from the Barron River. Twenty-eight species from 15 families were taken from the Mitchell River (Table 1).

\section{Fish community structure}

Figure 2 shows the DCA ordination plot for all study sites in the Barron and Mitchell catchments. There are three clear groups of sites: the Barron coastal sites, the Mitchell sites and non-coastal Barron sites upstream of the Barron Falls. The coastal sites and the Mitchell sites separate to opposite ends of DCA Axis 1. The Mitchell sites are all grouped closely, suggesting relative homogeneity. Similarly, lack of separation in ordination space, which suggests that differences between the various sub-catchments in the Barron River above the Barron Falls are not strongly defined, indicates a relatively homogeneous distribution of fish species. Further, despite the connectivity between the Mitchell and Barron catchments through the MareebaDimbulah irrigation system, possible linkage of the two systems during peak flood events and numerous attempted past translocations of selected species (predominantly of fish from western and some other eastern catchments into the Barron system), it would appear that the fish faunas at sites within the catchments remain largely heterogeneous. Coastal freshwater piscifauna, euryhaline species and marine vagrants are mostly distributed on the negative side of DCA Axis 1 (Fig. 3), whereas fish that are only found in the Mitchell system are located at the other end of the axis. The Mitchell Falls, which is situated downstream of the sampling sites, is a significant barrier to the upstream movement of euryhaline species. Between these groups are a suite of species including exotic, endemic and translocated fish that occur mostly in the Barron catchment above the Barron Falls (and some that are common to both catchments). Included in this grouping are several species that also occur in the coastal reaches of eastern streams, including the euryhaline $A$. reinhardtii and M. splendida splendida, Morgunda adspersa, Hephaestus tulliensis, Tandanus tandanus, Pseudomugil gertrudae and Hypseleotris galii. Anguilla reinhardtii, Melanotaenia splendida splendida and Morgunda adspersa are endemic to both coastal and non-coastal parts of the catchment, whereas the last three species have probably been translocated from other east coast or western streams.
Hephaestus tulliensis is a coastal species that has been stocked in non-coastal streams. Several other species occurring above the Barron Falls, including Oxyleotris lineolatus, O. selhemi, Porochilus rendahli and Ambassis macleayi are likely to have been translocated from western flowing drainages including the Mitchell catchment. Table 1 shows the fish species recorded in both catchments including exotic species and fish that are suspected, or known to have been, translocated. The crustacean, Cherax quadricarinatus, which is endemic to western-flowing drainages, is distributed widely throughout both catchments. Thirty fish species occurred above the Barron Falls and 28 species were identified from the Mitchell system, with 16 species or subspecies common to both catchments. In the coastal freshwater areas of the Barron catchment, 44 fish species were identified, 16 of which were also found above the Barron Falls. Although the exotic fish species Poecilia reticulata was identified from two sites in the upper Mitchell, there was no firm evidence of any translocated native species within this catchment. This is despite opportunities for translocation, either through the irrigation channel or connection by floods that periodically link the two catchments.

Figure 4 shows the average fish species diversity at sites in the Barron catchment over the period of the study. Species diversity in the coastal watercourses, particularly Freshwater Creek and the freshwater reaches of the Barron River below the falls, was relatively high (up to 2.5) owing to presence of marine vagrants and species with marine/estuarine phases of their life cycle. Seven sites on Freshwater Creek had a species diversity greater than two. Small ephemeral tributaries, which would need to be recolonised each year, predictably had lower species diversities (down to 0.6). Sites above the Barron Falls on the main Barron River or on tributary streams close to the Barron River also had high species diversities and their values did not substantially decrease as distance upstream increased. Species diversity in tributary streams decreased with increasing distance from the main Barron channel. It is likely that smaller ephemeral streams tended to be colonised by smaller species with shorter life cycles (e.g. M. splendida splendida) or aggressive colonisers that are able to withstand harsher conditions. Species diversity at sites on the upper reaches of some tributary streams was as low as 0.12 . The fish species diversity in the Barron River and larger watercourses immediately upstream of Tinaroo Dam was relatively high and was influenced by stocks of fish resident in the impoundment. Tinaroo Falls Dam acted as a barrier to upstream fish movement, even preventing passage of the euryhaline species Anguilla reinhardtii, which, significantly, was able to successfully negotiate the Barron Falls.

Current and historical species richness at sites in the freshwater sub-catchment were both high and similar, with the differences a result of the introduction of four exotic 
Table 1. Freshwater fish sampled in the coastal freshwater areas of the Barron catchment and the upper reaches of the Barron and Mitchell Rivers

\begin{tabular}{|c|c|c|c|c|}
\hline Family (common name) & Species & $\begin{array}{l}\text { Barron } \\
\text { (coastal) }\end{array}$ & $\begin{array}{c}\text { Barron } \\
\text { (non-coastal) }\end{array}$ & Mitchell \\
\hline Megalopidae (tarpon) & Megalops cyprinoides & + & & \\
\hline \multirow[t]{2}{*}{ Anguillidae (eels) } & Anguilla obscura & + & & \\
\hline & Anguilla reinhardtii & + & + & \\
\hline Clupeidae (herrings) & Nematalosa erebi & + & $+^{\mathrm{t}}$ & + \\
\hline \multirow[t]{6}{*}{ Chandidae (glass perchlets) } & Ambassis agassizi & & + & \\
\hline & Ambassis agrammus & & + & + \\
\hline & Ambassis gymnocephalus & + & & \\
\hline & Ambassis macleayi & & $+^{t}$ & + \\
\hline & Ambassis miops & + & + & \\
\hline & Ambassis vachellii & + & & \\
\hline \multirow[t]{2}{*}{ Ariidae (fork tailed catfish) } & Arius berneyi & & & + \\
\hline & Arius leptaspis & & & + \\
\hline \multirow[t]{4}{*}{ Plotosidae (eel tailed catfish) } & Neosilurus ater & + & $+^{\mathrm{t}}$ & + \\
\hline & Neosilurus hyrtlii & & + & + \\
\hline & Porochilus rendahli & & $+^{\mathrm{t}}$ & + \\
\hline & Tandanus tandanus & + & $+^{t}$ & \\
\hline Hemiramphidae (halfbeaks) & Arrhamphus sclerolepis & & & + \\
\hline Belonidae (needle fish) & Strongylura krefftii & & & + \\
\hline \multirow[t]{3}{*}{ Poeciliidae (live bearers) } & Gambusia holbrooki & $+*$ & & \\
\hline & Poecilia reticulata & $+*$ & $+*$ & $+*$ \\
\hline & Xiphophorus helleri & & $+*$ & \\
\hline Atherinidae (hardyheads) & Craterocephalus stercusmuscarum & + & $+^{\mathrm{t}}$ & + \\
\hline \multirow[t]{2}{*}{ Melanotaeniidae (rainbowfish) } & Melanotaenia splendida inornata & & & + \\
\hline & Melanotaenia splendida splendida & + & + & \\
\hline \multirow[t]{2}{*}{ Pseudomugilidae (blue eyes) } & Pseudomugil gertrudae & & $+^{\mathrm{t}}$ & \\
\hline & Pseudomugil signifer & + & & \\
\hline Synbranchidae (swamp-eels) & Ophisternon cf.bengalense & + & & \\
\hline Tetrarogidae (bullrouts) & Notesthes robusta & + & & \\
\hline Latidae (sea bass) & Lates calcarifer & + & & \\
\hline Chanidae (milk fish) & Chanos chanos & + & & \\
\hline \multirow[t]{8}{*}{ Terapontidae (grunters) } & Amniataba percoides & + & + & + \\
\hline & Hephaestus carbo & & & + \\
\hline & Hephaestus fuliginosus & + & $+^{\mathrm{t}}$ & + \\
\hline & Hephaestus tulliensis & + & $+^{\mathrm{t}}$ & \\
\hline & Leiopotherapon unicolor & + & + & + \\
\hline & Mesopristes argenteus & + & & \\
\hline & Pingalla gilberti & & & + \\
\hline & Scortum ogilbyi & & & + \\
\hline Kuhliidae (flag tails) & Kuhlia rupestris & + & & \\
\hline Apogonidae (cardinal fish) & Glossamia aprion & + & + & + \\
\hline Carangidae (trevally) & Caranx sexfasciatus & + & & \\
\hline Leiognathidae (ponyfish) & Leiognathus equula & + & & \\
\hline Lutjanidae (snappers) & Lutjanus argentimaculatus & + & & \\
\hline Gerreidae (silver-biddies) & Gerres filamentosus & + & & \\
\hline Scatophagidae (scats) & Scatophagus argus & + & & \\
\hline Toxotidae (archerfish) & Toxotes chatareus & + & $+^{\mathrm{t}}$ & + \\
\hline \multirow[t]{2}{*}{ Mugilidae (mullet) } & Liza subviridis & + & & \\
\hline & Mugil cephalus & + & & \\
\hline \multirow[t]{6}{*}{ Eleotridae (gudgeons) } & Bunaka gyrinoides & + & & \\
\hline & Eleotris fusca & + & & \\
\hline & Hypseleotris compressa & + & + & \\
\hline & Hypseleotris galii & & $+^{\mathrm{t}}$ & \\
\hline & Mogurnda adspersa & + & + & \\
\hline & Mogurnda cf.mogurnda & & + & + \\
\hline
\end{tabular}


Table 1. (continued)

\begin{tabular}{|c|c|c|c|c|}
\hline Family (common name) & Species & $\begin{array}{l}\text { Barron } \\
\text { (coastal) }\end{array}$ & $\begin{array}{c}\text { Barron } \\
\text { (non-coastal) }\end{array}$ & Mitchell \\
\hline & Ophieleotris margaritacea & + & & \\
\hline & Oxyeleotris lineolatus & & $+^{\mathrm{t}}$ & + \\
\hline & Oxyeleotris selheimi & & $+^{\mathrm{t}}$ & + \\
\hline \multirow[t]{9}{*}{ Gobiidae (gobies) } & Awaous acritosus & + & & \\
\hline & Glossogobius aureus & & & + \\
\hline & Glossogobius celebius & & + & \\
\hline & Glossogobius guirus & & + & \\
\hline & Redigobius bikolanus & + & & \\
\hline & Schismatogobius sp. & + & & \\
\hline & Sicyopterus sp. & + & & \\
\hline & Stenogobius sp. & + & & \\
\hline & Glossogobius sp. C & & & + \\
\hline \multirow{2}{*}{ Soleidae (soles) } & Brachirus salinarum & & & + \\
\hline & Brachirus selheimi & & & + \\
\hline \multirow[t]{2}{*}{ Cichlidae (cichlids) } & Oreochromis mossambicus & & $+*$ & \\
\hline & Tilapia mariae & $+*$ & & \\
\hline
\end{tabular}

*Exotic species; ${ }^{\mathrm{t}}$ translocated or possibly translocated species.

species rather than the translocation of native fish (Fig. 5). Current and historical species richness in the non-coastal sub-catchments were low when compared with the freshwater (coastal) sub-catchment; however, the addition of exotic and translocated fish substantially increased the species richness in each of the non-coastal sub-catchments (Fig. 5).

Translocated fish made up a higher proportion of the total fish caught in non-coastal Barron sites than in coastal sites (Fig. 6). At one non-coastal site, translocated fish comprised more than $62 \%$ of the total fish sampled. The total number of exotics (two species) and translocated fish (15 species) has almost quadrupled the number of fish species in the Tinaroo sub-catchment.

Average diversity of the 24 sites sampled in the Mitchell catchment ranged between 1.04 and 2.15 (see Fig. 4). Most sites were on the main Mitchell or Walsh Rivers and had high species diversities. Some sites in the upper catchment had lower species diversities, but diversities were not as low as those at similar geographically placed streams in the Barron catchment. In the final multiple regression model for the Mitchell catchment, only one term, height above sea level, could be related to the Shannon-Weiner diversity index and the amount of variation explained was only $17.7 \%$ (Table 2 ).

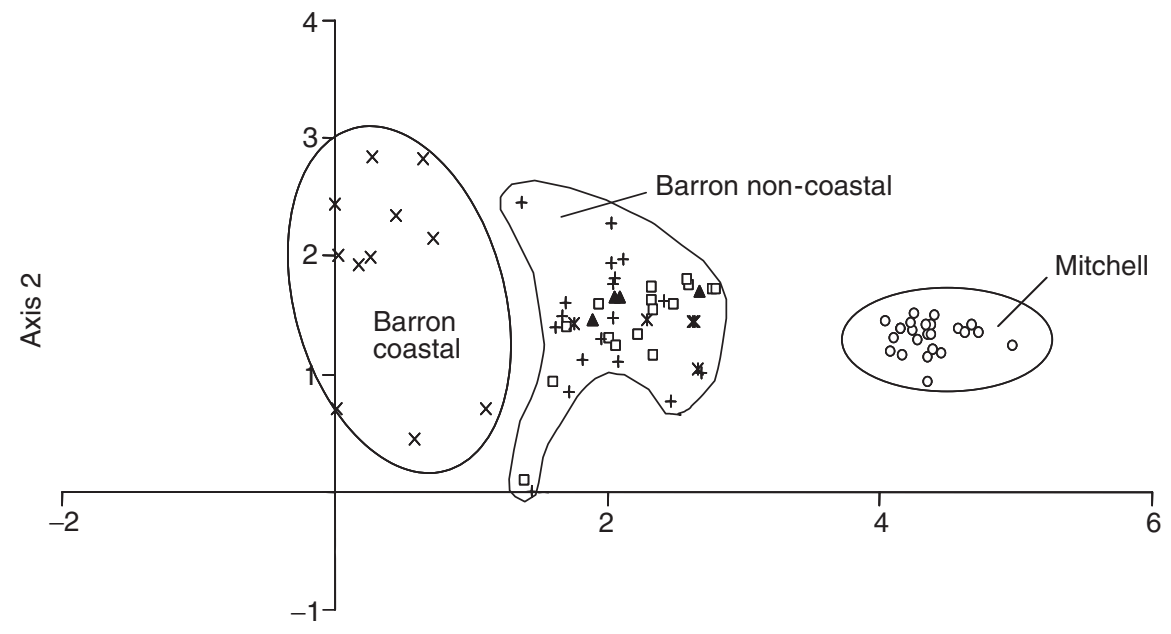

Axis 1

Fig. 2. Distribution of study sites in both catchments in ordination space using Detrended Correspondence Analysis. The Mitchell sites and the Barron coastal and non-coastal sites are grouped. Markers identify the Barron sub-catchments: $\times$, Freshwater; +, Tinaroo; $\square$, Middle; $*$, Flaggy; $\boldsymbol{\Delta}$, Clohesy-Davies. 


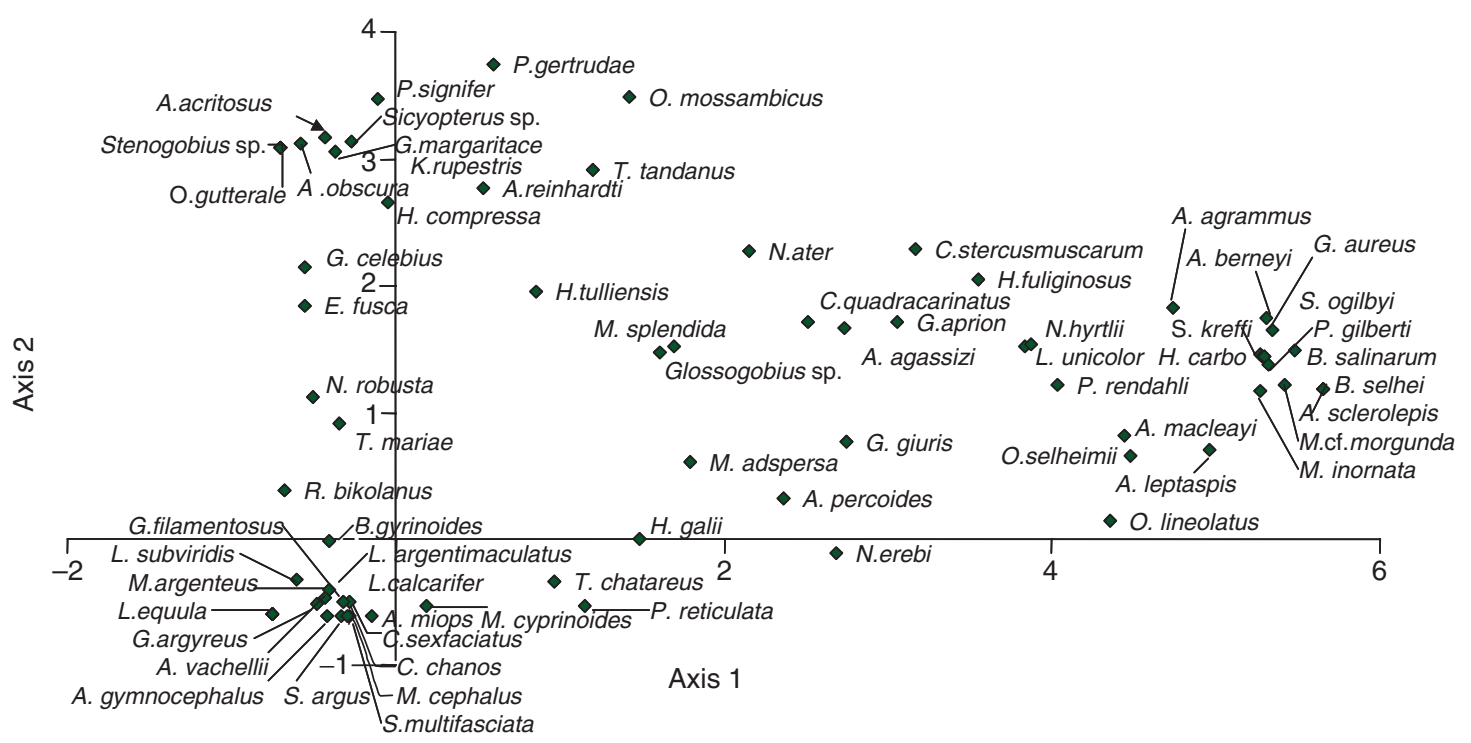

Fig. 3. Distribution of fish species (and Cherax quadricarinatus) from both catchments in the same ordination space as used in Fig. 2.

In the Barron catchment, a similar model could be significantly improved by using the terms height above sea level and suspended solids. These terms explained $50.4 \%$ of the variability in fish species diversity. No suitable model was found for species richness in the Mitchell catchment. The term 'height above sea level' significantly improved the GLM for species richness in the Barron catchment, explaining $58.3 \%$ of the variation.

\section{Exotic species}

Exotic fish were not widely distributed in either catchment. In the Barron catchment, five exotic fish species were caught at 15 of the 54 sites sampled, whereas only one species (Poecilia reticulata) was sampled at two sites in the Mitchell catchment (Table 1). In the Barron catchment, exotic fish made up higher proportions of the fish communities at coastal sites than non-coastal sites (Fig. 6). Poecilia reticulata was the numerically dominant species (80-100\%) during one or more sampling events at three of the non-coastal Barron sites, but generally comprised less than $10 \%$ of the catch. At three sites in the Barron catchment, $P$. reticulata was caught on a single occasion during the two years of sampling, suggesting that their numbers fluctuate. At an ephemeral site adjacent to an urban area, $P$. reticulata was the only species caught during one sampling event and was not caught on the other occasions the site was sampled.

At most sites where Oreochromis mossambicus were sampled, they were generally less than $15 \%$ of the total number of fish caught. However, at one site, on two occasions in 1997, this species made up 58\% and $76 \%$ of the catch. Most of the fish at this site were caught in beds of the exotic invasive grass Urochloa mutica and, on occasions, in relatively fast-flowing $\left(0.5-1 \mathrm{~m} \mathrm{sec}^{-1}\right)$ water. At sites in the lower catchment, Tilapia mariae never comprised more than $19 \%$ of the total catch and at most sites, on most occasions, was less than $10 \%$. During this study, O. mossambicus were only found in the Tinaroo sub-catchment and T. mariae were sampled in the coastal streams of the Barron catchment. There is evidence from previous studies (A. Hogan, Queensland Department of Primary Industries, personal communication) that small numbers of $T$. mariae were also present in the non-coastal sub-catchments. Gambusa affinis and Xiphophorus maculatus were sampled at single locations in the freshwater sub-catchment.

\section{Discussion}

Mechanisms responsible for the distribution of fish species in wet-tropics streams have been suggested in several studies (Beumer 1980; Pusey et al. 1995; Russell et al. 1998). Most Australian freshwater fish are of recent marine origin and many are dependent on accessing tidal waters during some stage of their life cycle. Therefore it is not surprising that several authors (e.g. Pusey et al. 1995; Russell et al. 1998) have noted an orderly change in species richness in Queensland wet-tropics streams corresponding to position within the catchment. However, other factors, including barriers to fish movement, are sufficiently important to sometimes obscure effects related to catchment position (Pusey et al. 1995). In the Barron catchment, the Barron Falls and major impoundments act to restrict fish movement, particularly of euryhaline species and marine vagrants, preventing an orderly upstream change in species richness. Changes tend to be abrupt. Under these circumstances and without anthropogenic influences, species richness and diversity in non-coastal parts of the Barron catchment would be expected to be poor. This is supported by earlier surveys 

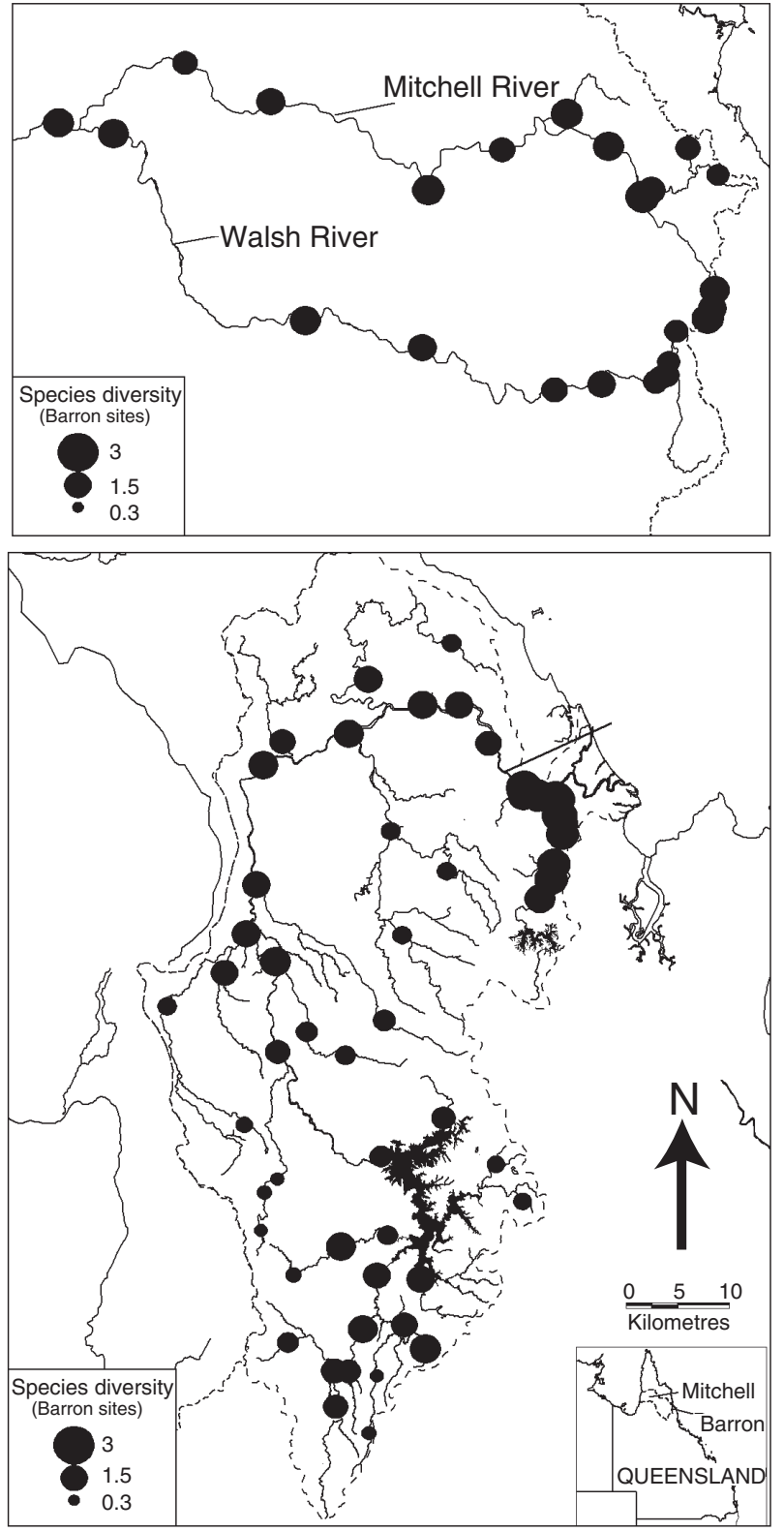

Fig. 4. Fish species diversity at sites in the Mitchell (top) and Barron (bottom) catchments.

(Shipway 1947a, 1947b, 1947c, 1948). However, the relatively recent but widespread anthropogenic-related translocation of native fishes and introductions of exotic species in the non-coastal sub-catchments has confounded the situation. Euryhaline and marine vagrant species were not found at the Mitchell catchment sites, probably largely due to their remoteness from the sea but also because a barrier (the Mitchell Falls) restricts upstream fish movement to all sites on the Mitchell River upstream of its confluence with the Walsh River.

Consequently, in the Barron catchment, fish assemblages in coastal streams were quite different to those in the rivers

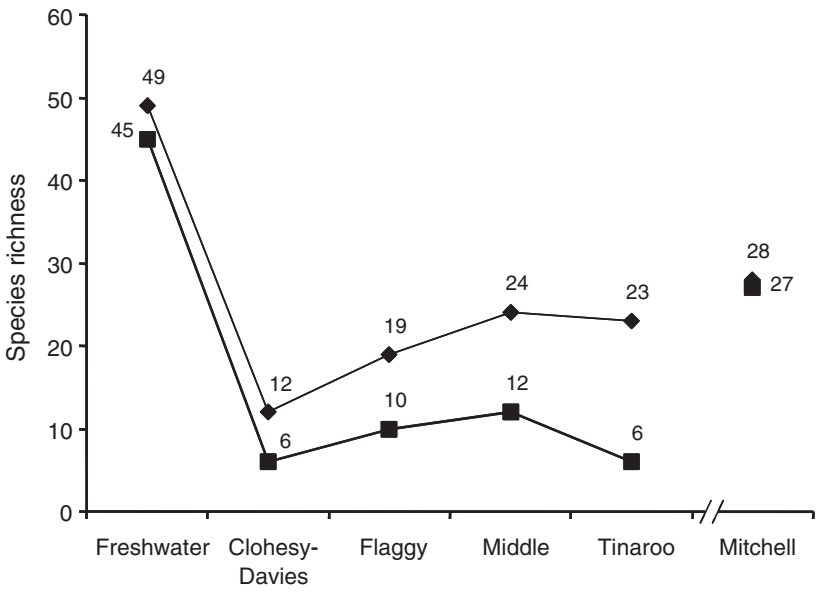

Fig. 5. Species richness in the Barron sub-catchments and the upper Mitchell catchment. Current species richness $(\diamond)$ was from sampling in this study, whereas historical species richness ( $)$ was estimated by removing exotic and translocated or possibly translocated species.

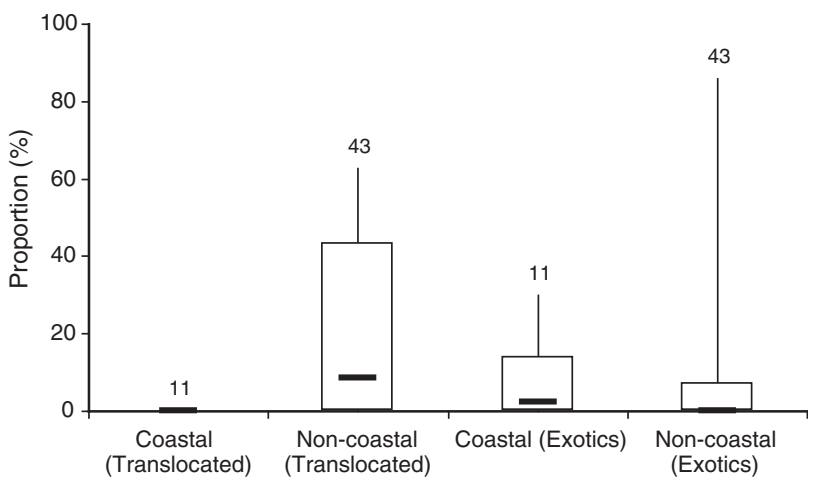

Fig. 6. Box and whisker plot showing the percentage of exotic or translocated fish at coastal and non-coastal sites in the Barron catchment. The box encloses the data between the $10^{\text {th }}$ and $90^{\text {th }}$ percentile, whereas the vertical lines at the top and bottom of the box show the range of data values. The horizontal bar is the median value and the numbers above each bar represent the total number of coastal or non-coastal sites.

and streams above the Barron Falls. There is little evidence to suggest that an interbasin link mediated by the irrigation system, or other possible conduits, such as occasional connection through floodwaters, has resulted in significant cross-catchment fish movements. This is despite the selective translocation of native fishes through anthropogenic activity from western draining streams, including the Mitchell system, into the Barron catchment. The presence of $P$. reticulata at two sites in the Mitchell catchment is more likely the result of a release from a domestic aquarium. Pusey et al. (1995) argued that constancy of discharge was a factor contributing to increased species richness in other wet-tropics watercourses. Relatively high species diversities in many of the streams in the upper Mitchell catchment, some of which historically 
Table 2. Regression equations relating Shannon-Weiner species diversity and species richness to environmental and geographic parameters

\begin{tabular}{lccc}
\hline Response variable & Catchment & Term & Coefficient \\
\hline Species diversity & Barron River & Constant & 0.7777 \\
& & Height above sea level $(\mathrm{m})$ & $-0.000811^{* *}$ \\
& Mitchell River & Suspended Solids $\left(\mathrm{mg} \mathrm{L}^{-1}\right)$ & $0.01851^{*}$ \\
& & Constant & 1.964 \\
Species richness & Barron River & Height above sea level & $-0.00115^{*}$ \\
& & Constant & 3.130 \\
& & Height above sea level $(\mathrm{m})$ & $-0.001752^{* *}$ \\
\hline
\end{tabular}

Adjusted $R^{2}$ for the Barron River was 50.4 and 17.7 for the Mitchell River. Adjusted $R^{2}$ for species richness $=58.31 . *$ Significance between 0.01 and $0.05 ; * * 0.001$ significance.

were probably low flow or ephemeral, were probably assisted by constancy of stream flow provided by discharge of waters from the irrigation scheme.

Coastal freshwater streams in the Barron catchment have relatively high species diversities and richness. Similar results have been noted in other wet-tropics streams in northern Australia (Hortle and Pearson 1990; Pusey et al. 1995; Pusey and Kennard 1996). Both species richness and diversity in the Barron catchment, and species diversity in the Mitchell catchment, were negatively related to height above sea level. There was also evidence that suspended solids also impacted on species diversity in the Barron catchment. Other studies in wet tropics streams (Pusey et al. 1995) have negatively related species diversity to position in the catchment (distance from the river mouth) and there is evidence in the literature, particularly for estuarine habitats, that turbidity is an important influence in determining fish distribution (e.g. Blaber and Blaber 1980; Blaber 1981; Cyrus and Blaber 1987; Cyrus 1992).

\section{Exotic and translocated species}

Some 21 species of Australian indigenous fish have been translocated and at least 21 species of exotic fish have established in Australian freshwaters (McKay 1989). Available evidence (Shipway 1947a, 1947b, 1947c, 1948; Pusey and Kennard, 1996) suggests that many of the freshwater species now present in the non-coastal parts of the Barron catchment have recently been translocated from other drainages or are introduced exotic species (e.g. $O$. mossambicus and $P$. reticulata). To date, other wet-tropics streams generally appear not to have been heavily impacted by exotic fish introductions. A recent survey of freshwater piscifauna at Barron River (Pusey and Kennard, 1996) found two exotic species: O. mossambicus at one site; and $P$. reticulata at three sites. Hortle and Pearson (1990) found no evidence of any exotic fishes, although other studies (Russell and Hales, 1993; Russell et al. 1996; Russell et al. 1998) have found evidence of restricted populations of $P$. reticulata and $T$. mariae in other north Queensland catchments. The Barron system, probably because of its concentrated urban centres and highly developed irrigation infrastructure, would appear to have a higher incidence of exotic fish colonisation and native fish translocations than other similar adjacent catchments. Fish stocking activities in north-eastern Queensland during most of the last half of the twentieth century have heavily targeted the Barron catchment, particularly Lake Tinaroo. There is no evidence available to indicate any significant stocking activities in the Mitchell catchment. There is, however, potential for cross-catchment migration of fish particularly through the interbasin transfer of irrigation water. McGuigan et al. (2000) reported M. s. splendida from the Tinaroo channel and further intensive sampling, targeting sites close to the channel outfalls in the Mitchell system may locate isolated populations of eastern drainage species such as M. s. splendida.

Identification of all species present in the non-coastal Barron catchment before the advent of fish stocking activities is problematic, but almost certainly included $M . s$. splendida, Mogunda adspersa, and A. reinhardtii. These species are sympatric in an adjacent stream, the Johnstone River, upstream of stream barriers (Pusey et al. 1995). An early survey of the fishes of the Barron River (Shipway $1947 a, 1947 b, 1947 c, 1948)$ identified 21 species of freshwater fish of which at least seven (A. reinhardtii, Melanotaenia cf. splendida splendida, Leiopotherapon unicolor, Mogunda adspersa, Neosilurus hyrtlii, H. compressa and Amniataba percoides) were found above the Barron Falls. Pusey and Kennard (1996) suggested that at least some of the five species that they sampled in the Barron River above the falls were translocated. They also speculated that the presence of L. unicolor, Craterocephalus stercusmuscarum, Hephaestus fuliginosus and Porochilus rendahli, all of which occur in westward flowing streams, may be present in the Barron as a result of long-term landscape evolution when the Barron River, which originally flowed into the Gulf of Carpentaria, was diverted into the eastern drainage during the early tertiary (Coventry et al. 1980). The rearrangement of stream channels has been suggested as a likely explanation for the similar genetic 
structures of some freshwater fish species on the Atherton Tablelands, including C. stercusmuscarum, M adspersa and Melanotaenia s. splendida (Hurwood and Hughes 1998; McGlashan and Hughes 2000; McGuigan et al. 2000; Hurwood and Hughes 2001). Levels of genetic divergence between coastal and inland populations of some species, and genetic similarities between populations of those species in different upland drainages, in the wet tropics suggest recent connectivity between wet-tropics drainages that are now geographically separated (McGlashan and Hughes 2001). McGlashan and Hughes (2000) found that specimens of C. stercusmuscarum from a site in the upper Barron were genetically similar to fish taken from sites in the adjacent upper North Johnstone River. They noted that Atherton Tableland populations are less divergent from Northern Territory individuals than Tableland stream populations are from their lowland river counterparts, suggesting that upland populations of this species may have derived from western flowing rivers. Genetic similarities of $M$. s. splendida present in the upland drainages of the Atherton Tableland Rivers may be the result of volcanism in north-eastern Australia some 10000 years ago (Hurwood and Hughes 2001). They suggested that larval flows at that time dammed several river drainages including Barron, Herbert, Johnstone and possibly the Walsh Rivers, thus facilitating widespread dispersal of this species.

Successful establishment of non-native fishes varies widely between geographic regions, but is generally more likely in areas that are either altered by man or initially depauperate in fish species (Ross 1991) and the potential for a successful introduction or translocation is greater when resource competition is minimal. The number of fish species present in the Barron River before the increase in stocking activities associated with the completion of Tinaroo Dam was relatively low and it is clear that there have since been quite a few successful native fish translocations into the Barron catchment. In addition to the fish, a translocated crustacean, Cherax quadricarinatus, a popular recreational and aquaculture species that is endemic to the Gulf drainages, is now widespread throughout the Barron catchment. Specimens of $C$. quadricarinatus were found at $49 \%$ of the sites sampled and the wide distribution was almost certainly originally a result of unauthorised introductions and/or from escapees from aquaculture farms. Effects of this translocation on endemic crustaceans were not investigated during this study.

The euryhaline fish Lates calcarifer was successfully stocked into Lake Tinaroo from the mid-1980s where it is now the basis of an important 'put and take' recreational fishery (Russell et al. 2000). However, despite its abundance in Lake Tinaroo, this species was not sampled in any of the non-coastal Barron streams, including tributary streams of Lake Tinaroo, during this study. This may be a result of a small waterfall in the Barron River immediately above the impoundment preventing upstream movement and also because the rapid growth of the species quickly makes it too large to inhabit other tributary streams.

Several of the exotic species that are established in the Barron catchment have the potential to disrupt and substantially change the existing fish communities. Populations of Tilapia mariae were established in the lower catchment and were separated by the Barron Falls and Tinaroo Dam from populations of O. mossambicus, which were recorded from multiple sites in the upper catchment and in Tinaroo Dam (A. Hogan, Queensland Department of Primary Industries, personal communication). As previously mentioned, pathways exist for cross-catchment migration of O. mossambicus into western drainages. There is limited information on effects that the introduction of $O$. mossambicus can have on fish communities and stream ecology in Australia. It was very successful when introduced into large tropical river systems such as the Laloki (Berra et al. 1975) and Sepik River (Coates 1987) systems in Papua New Guinea and in other parts of Australia (Arthington et al. 1984). Although only introduced relatively recently to the Barron catchment (c. late 1980s), O. mossambicus has colonised a large area of the catchment above and including parts of Lake Tinaroo. At one creek site, on two occasions, O. mossambicus made up $76 \%$ and $58 \%$ of the total numbers of fish caught. Some authors have identified positive outcomes from introducing tilapias (e.g. Coates 1987; Lowe-McConnell 1994). Lowe-McConnell (1994) believed that introduced detritovores/algivores, like many tilapias, may not be as invasive as piscivores and she saw a possible role for them when the zooplankton-feeding niche becomes enlarged by the creation of man-made lakes as the development of a clupeid fishery in Lake Kariba has shown. At the sites where T. mariae was sampled, the CPUE data suggest that the species does not dominate fish communities, but this should be viewed cautiously because the species is difficult to electrofish and, consequently, the CPUE data may underestimate abundance.

Poecilia reticulata was patchily distributed at only eight sites throughout the Barron River catchment and two sites in the Mitchell catchment. Most of the sites in which this species was established were in agricultural or urban areas that were characterised by high levels of disturbance and/or poor water quality. This supports observations that it is not uncommon to find poeciliids dominant in highly modified urban creeks (Arthington and Lloyd 1989). At one site in the upper catchment, $P$. reticulata was the dominant species ( $86 \%$ of the total catch), with almost all of the remaining fish consisting of $M$. adspersa. To highlight the patchy nature of their distribution in the catchment, no $P$. reticulata were sampled at an adjacent site on the same creek, $\sim 6 \mathrm{~km}$ downstream. At this site Melanotaenia splendida splendida was the dominant species (97\% of the total catch), with almost all of the remaining catch consisting of Mogunda 
adspersa. Fish communities in small streams in the upper parts of geographically similar catchments are usually low in species diversity and may be dominated by M. adspersa (Pusey et al. 1995).

Other exotics found in very low numbers in the Barron catchment include Xiphophorus helleri and Gambusia holbrooki. The latter species, which can have adverse impacts on native fish (Ivantsoff and Aarn, 1999) was introduced into the area nearly 60 years ago (McKay, 1984) but has not become widely established in this or other wet tropics streams (Pusey and Kennard, 1994; Pusey et al. 1995; Pusey and Kennard, 1996), despite being widely distributed in other parts of Australia (McKay, 1984; Arthington and Lloyd, 1989; McKay, 1989). McKay (1984) noted that fast flowing rivers and streams were not suited to mosquito fish and that, when present, they generally inhabit quieter backwaters away from the main current. Not all introductions have been successful and despite several attempts at stocking (Grant, 1975), populations of Salmo trutta and S. gairdnerii have never become established in the Barron catchment, probably because of high water temperatures.

In the literature there is a range of views on the effects that introduced fish can have on native fish communities. Simberloff (1997) noted that in $79 \%$ of cases, introduced species have had no effect on species in the resident communities, but Herbold and Moyle (1986) presented data that showed that introductions made into undisturbed habitats usually displace native species, often through competition. In his review Ross (1991), noted 'only two cases where transplanted fishes have had widespread success following introductions to drainages with relatively high diversities'. This would suggest that recent or further introductions to the Barron system would have a reduced probability of success and may help to explain the lack of translocated species in coastal freshwaters of the Barron catchment.

Over about the last fifty years, translocation of native fishes and, to some extent, the introduction of exotic fish, has changed the composition of fish communities in the Barron catchment. Anthropogenic activities, particularly inter-basin water transfers, have the potential to inadvertently alter the fish community composition and ecology in the Mitchell catchment. This is preventable through public education and other possible safeguards, for example physical or electrical barriers, need to be evaluated and if effective, implemented. Channel screens capable of preventing downstream dispersal of tilapia including their eggs are being considered for installation. The Gulf of Carpentaria drainage is relatively flat and seasonal monsoonal rains often result in the linking of the large river systems. In the event of exotic fish, particularly tilapia, becoming established in the extensive lagoons and watercourses of the Mitchell catchment, it is possible that monsoonal flooding will provide an efficient mechanism for the species to quickly spread across much of northern Australia.

\section{Acknowledgments}

We wish to thank Dr Michael Hutchison, Dr Brad Pusey and an anonymous referee for constructive comments on earlier drafts of this manuscript. We also acknowledge the technical support and advice given by Dr Lex Cogle, Ms Joanne de Faveri, Mr Scott Foster, Mr Alf Hogan, Mr Paul Langford and Ms Angela Reid. The work was partially funded by a grant from the National Heritage Trust.

\section{References}

Allen, G. R. (1989). 'Freshwater Fishes of Australia.' (T. F. H. Publications: Neptune City, NJ, USA.)

Arthington, A. H. (1989). Impacts of introduced and translocated freshwater fishes in Australia. In Proceedings of a Workshop on the Introduction of Exotic Organisms in Asia'. Vol. 3. (Ed. S. S. de Silva.) pp. 7-20. (Asian Fisheries Society: Manila, Philippines.)

Arthington, A. H., and Lloyd, L. N. (1989). Introduced poeciliids in Australia and New Zealand. In 'Ecology and Evolution of Livebearing Fishes'. (Eds G. K. Meffe and F. F. Snelson.) pp. 333-348. (Prentice Hall: Englewood Cliffs, NJ, USA.)

Arthington, A. H., McKay, R. J., Russell, D. J., and Milton, D. A. (1984). Occurrence of the introduced cichlid Oreochromis mossambicus (Peters) in Queensland. Australian Journal of Marine and Freshwater Research 35, 267-272.

Barlow, C. G., Hogan, A. E., and Rodgers, L. J. (1987). Implication of translocated fishes in the apparent extinction in the wild of the Lake Eacham rainbowfish, Melanotaenia eachamensis. Australian Journal of Marine and Freshwater Research 38, 897-902.

Berra, T. M., Moore, R., and Reynolds, L. F. (1975). The freshwater fishes of the Laloki River system of New Guinea. Copeia 2, 316-326.

Beumer, J. P. (1980). Hydrology and fish diversity of a north Queensland tropical stream. Australian Journal of Ecology 5, 59-86.

Blaber, S. J. M. (1981). The zoogeographic affinities of estuarine fishes in south-east Africa. South African Journal of Science 77, 305-307.

Blaber, S. J. M., and Blaber, T. G. (1980). Factors affecting the distribution of juvenile estuarine and inshore fish. Journal of Fish Biology 17, 143-162.

Carr, M. R. (1996). 'PRIMER user manual - Plymouth routines in multivariate ecological research.' (Plymouth Marine Laboratory: Plymouth, UK.)

Coates, D. (1987). Consideration of fish introductions into the Sepik River, Papua New Guinea. Aquaculture and Fisheries Management 18, 231-241.

Coventry, R. J., Hopley, D., Campbell, J. B., Douglas, I., Harvey, N., Kershaw, P., Oliver, J., Phipps, C. V. G., and Pye, K. (1980). The quaternary of northeastern Australia. In 'The Geology and Geophysics of North Eastern Australia'. (Eds R. A. Henderson and P. J. Stephenson.) pp. 375-417. (Geological Society of Australia: Brisbane, Australia.)

Cyrus, D. P. (1992). Turbidity gradients in two Indo-Pacific estuaries and their influence on fish distribution. South African Journal of Aquatic Science 18, 51-63.

Cyrus, D. P., and Blaber, S. J. M. (1987). The influence of turbidity on juvenile marine fishes in estuaries. Part 1. Field studies at Lake St. Lucia on the southeastern coast of Africa. Journal of Experimental Marine Ecology 109, 53-70, doi:10.1016/0022-0981(87)90185-7.

Grant, E. M. (1975). 'Guide to Fishes.' (Queensland Coordinator General's Department: Brisbane, Australia.)

Herbold, B., and Moyle, P. B. (1986). Introduced species and vacant niches. The American Naturalist 128, 751-760, doi:10.1086/ 284600. 
Hill, M. O. (1979). 'DECORANA: A Fortran Program for Detrended Correspondence Analysis and Reciprocal Averaging.' (Ecology and Systematics, Cornell University: Ithaca, NY, USA.)

Hortle, K. G., and Pearson, R. G. (1990). Fauna of the Annan River system, far north Queensland, with reference to the impact of tin mining. 1. Fishes. Australian Journal of Marine and Freshwater Research 41, 677-694.

Hurwood, D. A., and Hughes, J. M. (1998). Phylogeography of the freshwater fish, Mogurnda adspersa, in streams of northeastern Queensland, Australia: evidence for altered drainage patterns. Molecular Ecology 7, 1507-1517, doi:10.1046/J.1365-294X.1998. 00469.X.

Hurwood, D. A., and Hughes, J. M. (2001). Historical interdrainage dispersal of eastern rainbowfish from the Atherton Tableland, north-eastern Australia. Journal of Fish Biology 58, 1125-1136, doi:10.1006/JFBI.2000.1523.

Ivantsoff, W., and Aarn. (1999). Detection of predation on Australian native fishes by Gambusia holbrooki. Marine and Freshwater Research 50, 467-468, doi:101071/MF98106.

Lake, J. S. (1971). 'Freshwater Fishes and Rivers of Australia.' (Thomas Nelson: Melbourne, Australia.)

Lowe-McConnell, R. (1994). Threats to, and conservation of, tropical freshwater fishes. Mitteilungen der Internationalen Verinigung fur Theorestische und angewandte Limnologie 24, 47-52.

McGlashan, D. J., and Hughes, J. M. (2000). Reconciling patterns of genetic variation with stream structure, earth history and biology in the Australian freshwater fish Craterocephalus stercusmuscarum (Atherinidae). Molecular Ecology 9, 1737-1751, doi:10.1046/ J.1365-294X.2000.01054.X.

McGlashan, D. J., and Hughes, J. M. (2001). Genetic evidence for historical continuity between populations of the Australian freshwater fish Craterocephalus stercusmuscarum (Atherinidae) east and west of the Great Dividing Range. Journal of Fish Biology 59, 55-67, doi:10.1006/JFBI.2001.1758.

McGlashan, D. J., and Hughes, J. M. (2002). Extensive genetic divergence among populations of the Australian freshwater fish, Pseudomugil signifer (Pseudomugilidae), at different hierarchical scales. Marine and Freshwater Research 53, 897-907, doi:10.1071/MF01107.

McGuigan, K., Zhu, D., Allen, G. R., and Moritz, C. (2000). Phylogenetic relationships and historical biogeography of melanotaeniid fishes in Australia and New Guinea. Marine and Freshwater Research 51, 713-723, doi:10.1071/MF99159.

McKay, R. J. (1984). Introductions of exotic fishes in Australia. In 'Distribution, Biology and Management of Exotic Fishes'. (Eds W. J. Courtenay, Jr., and J. R. Stauffer, Jr.) pp. 177-199. (Johns Hopkins University Press: Baltimore, MD, USA.)

McKay, R. J. (1989). Exotic and translocated freshwater fishes in Australia. In 'Exotic Aquatic Organisms in Australia. Proceedings of the workshop on introduction of exotic aquatic organisms in Asia. Asian Fisheries Society Special Publication.' Vol. 3. pp. 21-34. (Asian Fisheries Society: Manila, Philippines.)
Pusey, B. J., and Kennard, M. J. (1994). The Freshwater Fauna of the Wet Tropics Region of Northern Queensland. Unpublished report to the Wet Tropics Management Authority (Cairns, Australia).

Pusey, B. J., and Kennard, M. J. (1996). Species richness and geographical variation in assemblage structure of the freshwater fish fauna of the wet tropics region of northern Queensland. Marine and Freshwater Research 47, 563-573.

Pusey, B. J., Arthington, A. H., and Read, M. G. (1995). Species richness and spatial variation in fish assemblage structure in two rivers of the Wet Tropics of northern Queensland, Australia. Environmental Biology of Fishes 42, 181-199.

Pusey, B. J., Bird, J., Kennard, M. J., and Arthington, A. H. (1997). Distribution of the Lake Eacham Rainbowfish in the Wet Tropics Region, North Queensland. Australian Journal of Zoology 45, 75-84.

Ross, S. T. (1991). Mechanisms structuring stream fish assemblages: are there lessons from introduced species? Environmental Biology of Fishes 30, 359-368.

Russell, D. J., and Hales, P. W. (1993). 'Stream Habitat and Fisheries Resources of the Johnstone River Catchment.' (Queensland Department of Primary Industries: Brisbane, Australia.)

Russell, D. J., Hales, P. W., and Helmke, S. A. (1996). 'Stream Habitat and Fish Resources in the Russell and Mulgrave Rivers Catchment.' (Queensland Department of Primary Industries: Brisbane, Australia.)

Russell, D. J., McDougall, A. J., and Kistle, S. E. (1998). 'Stream Habitat and Fish Resources of the Daintree, Saltwater, Mossman and Mowbray Catchments.' (Queensland Department of Primary Industries: Brisbane, Australia.)

Russell, D. J., McDougall, A. J., Ryan, T. J., Kistle, S. E., Aland, G., Cogle, A. L., and Langford, P. A. (2000). 'Natural Resources of the Barron River Catchment 1. Stream Habitat, Fisheries Resources and Biological Indicators.' QI00032. (Queensland Department of Primary Industries: Brisbane, Australia.)

Shipway, B. (1947a). Fresh water fishes of the Barron River. North Queensland Naturalist 14, 25-27.

Shipway, B. (1947b). Fresh water fishes of the Barron River. North Queensland Naturalist 15, 5-7.

Shipway, B. (1947c). Fresh water fishes of the Barron River. North Oueensland Naturalist 15, 9-21.

Shipway, B. (1948). Fresh water fishes of the Barron River. North Oueensland Naturalist 15, 20-21.

Simberloff, D. (1997). The biology of invasions. In 'Strangers in Paradise'. (Eds D. Simberloff, D. C. Schmitz and T. C. Brown.) pp. 3-19. (Island Press: Washington, DC, USA.)

Manuscript received 8 April 2002; revised and accepted 18 August 2003. 